\title{
Trend of crop water requirement at Akola (Maharashtra), India
}

\author{
J. N. Lokhande, M. U. Kale* and S. B. Wadatkar \\ Department of Irrigation and Drainage Engineering, Dr. Panjabrao Deshmukh Krishi Vidyapeeth, Akola-444104 (MS), \\ INDIA \\ *Corresponding author. E-mail: kale921@gmail.com \\ Received: June 23, 2016 : Revised received: November 5, 2016 Accepted: february 13, 2017
}

\begin{abstract}
Climate change scenario badly affects the agriculture. The present study aimed to characterize the trend in maximum temperature and crop water requirement over a last decade at Akola station (Maharashtra State), because of changing trend in meteorological parameters. Study investigated the trends in temperature and reference evapotranspiration using various statistical parameters like mean, coefficient of variation, coefficient of skewness and coefficient of kurtosis. Monthly maximum air temperature showed slightly decreasing trend over summer season while increasing trend over monsoon and winter season. On the contrary, the monthly reference evapotranspiration showed decreasing linear trend over monsoon and winter season, while increasing trend over summer season. The study concluded that as the monthly reference evapotranspiration showed decreasing linear trend over cropping seasons (i.e. monsoon and winter), the crop water requirement at Akola station shall decrease in future.
\end{abstract}

Keywords: Climate change, Evapotranspiration, Moving averages, Temperature, Trend analysis

\section{INTRODUCTION}

In recent years, global warming, arising from anthropogenic-driven emissions of greenhouse gases, has become an important issue all over the globe. The well -acknowledged global warming and climate change may also have far reaching consequences for the common people who depend on natural resources, including water for their livelihood (Jhajharia et al., 2013).

Most of the observed increase in temperature since the mid- $20^{\text {th }}$ century is very likely due to the observed increase in greenhouse gas concentrations. One would expect an increase in evaporation in view of the rise in temperature. But, in recent decade, it has been observed that the evaporation has been decreasing in various parts of the world. This contrasting situation i.e., decrease in evaporation under rising temperature, is called as the evaporation paradox (Xiaomong et al. 2011).

The rainfall and temperature is the most fundamental physical parameter among the climate as it determines the environmental factors of the particular region which affects the agricultural productivity. The annual mean temperature of India as a whole has risen by $0.51^{\circ} \mathrm{C}$ over the period 1901-2005 (Fulekar and Kale, 2010). A number of scientific research study shown that surface air temperature increased about 0.2 to $0.6^{\circ}$ $\mathrm{C}$ during last century (Abaurrea and Cerian, 2001) and further it may increase by about 1.5 to $4.5^{\circ} \mathrm{C}$ until 2100 (Rajendra, 2004). This rate of increase may vary in different geographical regions.

The global warming affects the local climate differently. Crop water requirement depends on climate, soil and growth stage of crop. Thus Crop water requirement varies from location to location. Therefore location specific studies are needed to study the trends in crop water requirement. The present study was carried out with the main objective of investigating the trends in crop water requirement (reference evapotranspiration) along with pan evaporation and temperature for Akola station.

\section{MATERIALS AND METHODS}

Data: Daily meteorological data viz. maximum temperature (Tmax), minimum temperature (Tmin), bright sunshine hours (BSH), wind speed (Ws), morning relative humidity (RH-I), evening relative humidity $(\mathrm{RH}-$ II) etc were collected from Agricultural Meteorological Observatory, Dr. PDKV, Akola for the period of 2005 - 2014 (10 years).

Determination of reference evapotranspiration (ETo) : FAO version of Penman-Monteith model is so accurate that it is recommended as the sole method of calculating ETo if data are available (Allen et al., 1998) and is expressed as:

$$
\mathrm{ET}_{\mathrm{o}}=\frac{0.408 \Delta\left(\mathrm{R}_{\mathrm{n}}-\mathrm{G}\right)+\gamma \frac{900}{\mathrm{~T}+273} \mathrm{U}_{2}\left(\mathbf{e}_{\mathrm{s}}-\mathbf{e}_{\mathrm{a}}\right)}{\Delta+\gamma\left(1+0.34 \mathrm{u}_{2}\right)}
$$

where,

$$
\begin{aligned}
\text { ETo }= & \text { Reference evapotranspiration }\left(\mathrm{mm} \mathrm{day}^{-1}\right), \\
\square \quad & \text { Slope of saturation vapour pressure curve } \\
& \left(\mathrm{kPa}{ }^{\circ} \mathrm{C}^{-1}\right), \\
\mathrm{T} \quad= & \text { Mean air temperature }\left({ }^{\circ} \mathrm{C}\right), \\
\mathrm{g} \quad= & \text { Psychometric constant }\left(\mathrm{kPa}{ }^{\circ} \mathrm{C}^{-1}\right),
\end{aligned}
$$


$\mathrm{R}_{\mathrm{n}} \quad=$ Net radiation at the crop surface $\left(\mathrm{MJ} \mathrm{m}^{-2}\right.$ day $^{-1}$ ),

$\mathrm{G}=$ Soil heat flux density $\left(\mathrm{MJ} \mathrm{m}^{-2}\right.$ day $\left.^{-1}\right)$,

$\mathrm{u}_{2}=$ Wind speed at $2.0 \mathrm{~m}$ height $\left(\mathrm{ms}^{-1}\right)$,

$\mathrm{e}_{\mathrm{a}} \quad=$ Actual vapour pressure $(\mathrm{kPa})$,

$\mathrm{e}_{\mathrm{s}} \quad=$ Saturation vapour pressure $(\mathrm{kPa})$,

$\mathrm{e}_{\mathrm{s}}-\mathrm{e}_{\mathrm{a}}=$ Saturation vapour pressure deficit $(\mathrm{kPa})$.

Statistical tests: Data of temperature and estimated ETo were analysed statistically to test its variability, by determining average, standard deviation, coefficient of variation, skewness and kurtosis. These statistical tests are described below in brief.

Average (m): The average is the average value of the data. It is a measure of locality, i.e. the centre of mass of the histogram.

$$
\mathrm{m}=\frac{1}{\mathrm{n}} \sum_{\mathrm{i}=1}^{\mathrm{n}} \mathrm{z}_{\mathrm{i}}
$$

where, $n$ the number data and $z_{i}$ the value of the $i^{\text {th }}$ observation.

Standard deviation: The standard deviation is a measure of spread. It has the same units as the original variable. It is calculated as the square-root of the variance.

$$
\begin{aligned}
\mathrm{S}_{\mathrm{z}} & =\sqrt{\mathrm{S}_{\mathrm{z}}^{2}} \\
& =\sqrt{\frac{1}{\mathrm{n}} \sum_{\mathrm{i}=1}^{\mathrm{n}}\left(\mathrm{z}_{\mathrm{i}}-\mathrm{m}_{\mathrm{x}}\right)^{2}}
\end{aligned}
$$

Coefficient of variation: The coefficient of variation is also measure of spread that is relative to the magnitude of the variable considered. It is calculated as below.

$$
\mathrm{CV}_{\mathrm{z}}=\frac{\mathrm{s}_{\mathrm{z}}}{\mathrm{m}_{\mathrm{z}}}
$$

This measure only makes sense for variables with strictly positive values.

Skewness: The skewness of the frequency distribution describe whether it is symmetrical around its central
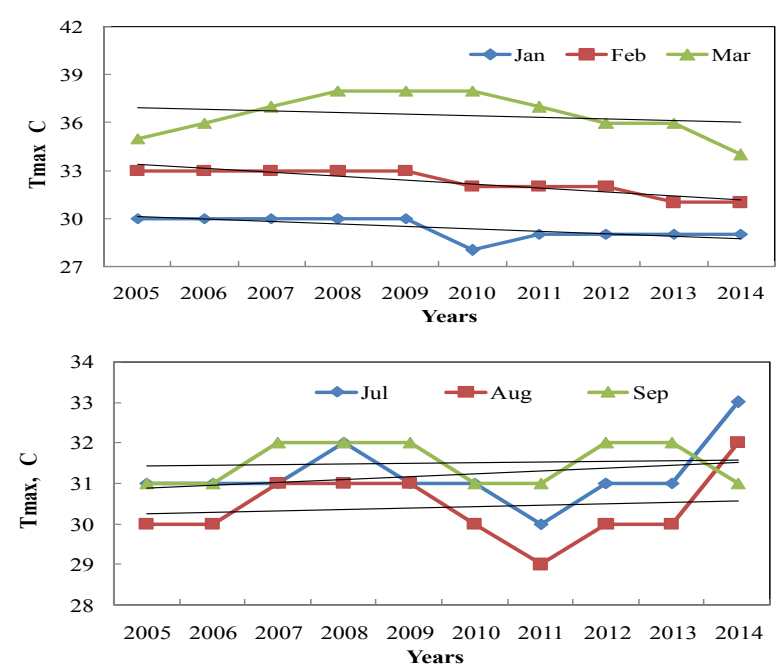

value or whether it is asymmetrical with a longer tail to the left $(<0)$ or to the right $(>0)$. It is calculated using following relationship.

$$
\mathrm{CS}_{\mathrm{z}}=\frac{\frac{1}{\mathrm{n}} \sum_{\mathrm{i}=1}^{\mathrm{n}}\left(\mathrm{z}_{\mathrm{i}}-\mathrm{m}_{\mathrm{x}}\right)^{3}}{\mathrm{~s}_{\mathrm{z}}^{3}}
$$

Kurtosis: The kurtosis measures the 'peakedness' of the frequency distribution and is calculated from the data as

$$
\mathrm{CC}_{\mathrm{z}}=\frac{\frac{1}{\mathrm{n}} \sum_{\mathrm{i}=1}^{\mathrm{n}}\left(\mathrm{z}_{\mathrm{i}}-\mathrm{m}_{\mathrm{z}}\right)^{4}}{\mathrm{~s}_{\mathrm{z}}^{4}}-3
$$

The kurtosis compared the peakedness of the distribution with that of a normal distribution. It is either more peaked when larger than zero or flatter when smaller than zero.

Moving average technique: The trends in temperature and ETo were studied by using moving average technique. The moving average is a weighted mean of previous end data of weather parameter. For 10 month simple moving average of weather parameter is the mean of the previous weather parameters i.e. $\mathrm{P}_{\mathrm{M}}, \mathrm{P}_{\mathrm{M}-1}$, $\mathrm{P}_{\mathrm{M}-2, \ldots \ldots}, \ldots \mathrm{P}_{\mathrm{M}-9}$ and is given as

Moving average $=\frac{\mathrm{P}_{\mathrm{M}}+\mathrm{P}_{\mathrm{M}-1}+\ldots \ldots+\mathrm{P}_{\mathrm{M}-9}}{10}$

When calculating successive values, a new value comes into the sum and old value drop out, meaning a full summation each time. Three years moving averages were carried out and plotted to check the trends existed in each parameter.

\section{RESULTS AND DISCUSSION}

The results of the study are discussed in the following subsections.

Maximum air temperature: Table 1 presents the statistical characteristics of mean monthly maximum air temperature for 10 years.
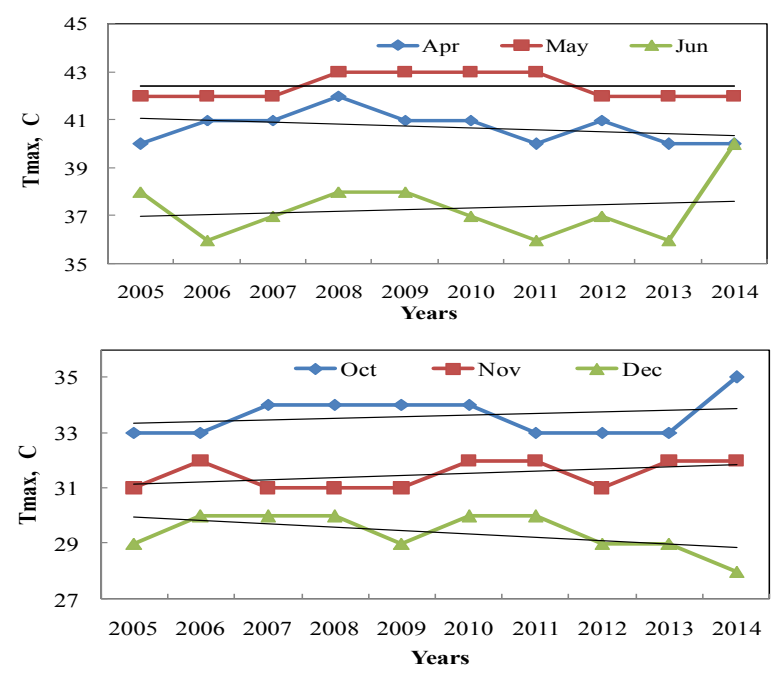

Fig. 1. Three years moving average trends in mean monthly maximum air temperature. 
J. N. Lokhande et al. / J. Appl. \& Nat. Sci. 9 (1): 441 - 444 (2017)

Table 1: Statistical characteristics of mean monthly maximum air temperature.

\begin{tabular}{lccccc}
\hline Month & $\begin{array}{c}\text { Mean } \\
\text { Temp., }{ }^{\circ} \mathbf{C}\end{array}$ & $\begin{array}{c}\text { Standard devia- } \\
\text { tion, }{ }^{\circ} \mathbf{C}\end{array}$ & $\begin{array}{c}\text { Coefficient of vari- } \\
\text { ation, } \%\end{array}$ & $\begin{array}{c}\text { Coefficient of } \\
\text { skewness }\end{array}$ & $\begin{array}{c}\text { Coefficient of kur- } \\
\text { tosis }\end{array}$ \\
\hline January & 29.32 & 1.07 & 3.64 & 1.86 & 4.11 \\
February & 32.44 & 1.51 & 4.64 & 0.90 & 0.15 \\
March & 36.66 & 1.51 & 4.13 & -0.92 & 0.17 \\
April & 40.80 & 0.98 & 2.40 & 0.55 & 0.14 \\
May & 42.25 & 0.78 & 1.85 & -0.01 & -0.13 \\
June & 37.33 & 2.10 & 5.62 & -0.70 & 0.88 \\
July & 31.20 & 1.02 & 3.28 & -0.57 & 0.54 \\
August & 30.20 & 1.30 & 4.32 & -0.01 & -0.39 \\
September & 31.45 & 0.74 & 2.37 & 1.53 & 2.43 \\
October & 33.40 & 1.04 & 3.13 & 0.02 & -0.68 \\
November & 31.43 & 0.86 & 2.74 & 0.11 & -0.36 \\
December & 29.46 & 1.04 & 3.53 & 0.62 & 0.30 \\
\hline
\end{tabular}

Table 2: Statistical characteristics of mean monthly reference evapotranspiration.

\begin{tabular}{lccccc}
\hline Month & Mean mmday $^{-1}$ & $\begin{array}{c}\text { Standard devia- } \\
\text { tion } \text { mmday }^{\mathbf{1}}\end{array}$ & $\begin{array}{c}\text { Coefficient of } \\
\text { variation \% }\end{array}$ & $\begin{array}{c}\text { Coefficient of } \\
\text { skweness }\end{array}$ & $\begin{array}{c}\text { Coefficent of } \\
\text { kurtosis }\end{array}$ \\
\hline January & 3.82 & 0.10 & 0.03 & -0.36 & -0.67 \\
February & 4.14 & 0.31 & 0.08 & 0.29 & -1.22 \\
March & 3.99 & 0.14 & 0.04 & -0.62 & -0.91 \\
April & 2.99 & 0.28 & 0.09 & -0.94 & -0.05 \\
May & 1.64 & 0.49 & 0.30 & -0.41 & 0.19 \\
June & 2.39 & 0.32 & 0.13 & 0.25 & 0.25 \\
July & 3.12 & 0.10 & 0.03 & -0.31 & 1.67 \\
August & 3.28 & 0.08 & 0.02 & 0.37 & 0.28 \\
September & 3.36 & 0.07 & 0.02 & 0.42 & 0.11 \\
October & 4.01 & 0.20 & 0.05 & -0.27 & -0.17 \\
November & 4.50 & 0.25 & 0.06 & -0.88 & 2.54 \\
December & 4.83 & 0.11 & 0.02 & 0.65 & -0.96 \\
\hline
\end{tabular}

It is seen from Table 1 that the mean monthly maximum air temperature varied between $29.32-42.25^{\circ} \mathrm{C}$. Highest maximum air temperature was found during the month of May, whereas lowest maximum air temperature was found during month of January. The coefficient of variation ranged between $1.85-5.62$ which indicated the variation in maximum air temperature. Variation did not show any particular pattern either season wise or month wise. Table 1 indicates that the monthly maximum air temperature series is mostly positively skewed, whereas kurtosis was found to be varying between -0.13 to 4.11 . Three years moving average trends in mean monthly maximum air temperature is depicted in Fig. 1.

It is seen from Fig. 1 that monthly maximum air temperature showed linear slightly decreasing trend for the months January to May and December, whereas for months from June to November, it showed increasing trend. Hence it was concluded that in general there was slightly decreasing trend in monthly maximum air temperature during summer season while increasing trend over monsoon and winter season. The results are in conformity with those of Jhajharia and Singh (2011), Jhajharia et al. (2014) and Deshmukh et al. (2015).
Reference Evapotranspiration: The statistical characteristics of mean monthly reference evapotranspiration for the period of 10 years are presented Table 2 .

It is seen from Table 2 that the mean monthly reference evapotranspiration varied from 1.64 to 4.83 mmday $^{-1}$. The coefficient of variation ranged between 0.02 to $0.30 \%$, which indicated variations in monthly reference evapotranspiration throughout the year. Table 2 indicated that monthly reference evapotranspiration series mostly positively skewed, whereas kurtosis was found in the range of -1.22 to 2.54 . Three years moving average of monthly reference evapotranspiration were estimated and plotted month wise as shown in Fig. 2.

It was seen that monthly reference evapotranspiration showed the decreasing linear trend for April, August, September, October, November and December, while increasing trend for February, March and June. However, for January, May and July, monthly reference evapotranspiration showed the somewhat constant linear trend. In general, the monthly reference evapotranspiration showed the decreasing linear trend over monsoon and winter season, whereas increasing trend over summer season. The results are in conformity with those of Jhajharia et al. (2014) and Deshmukh et al. 

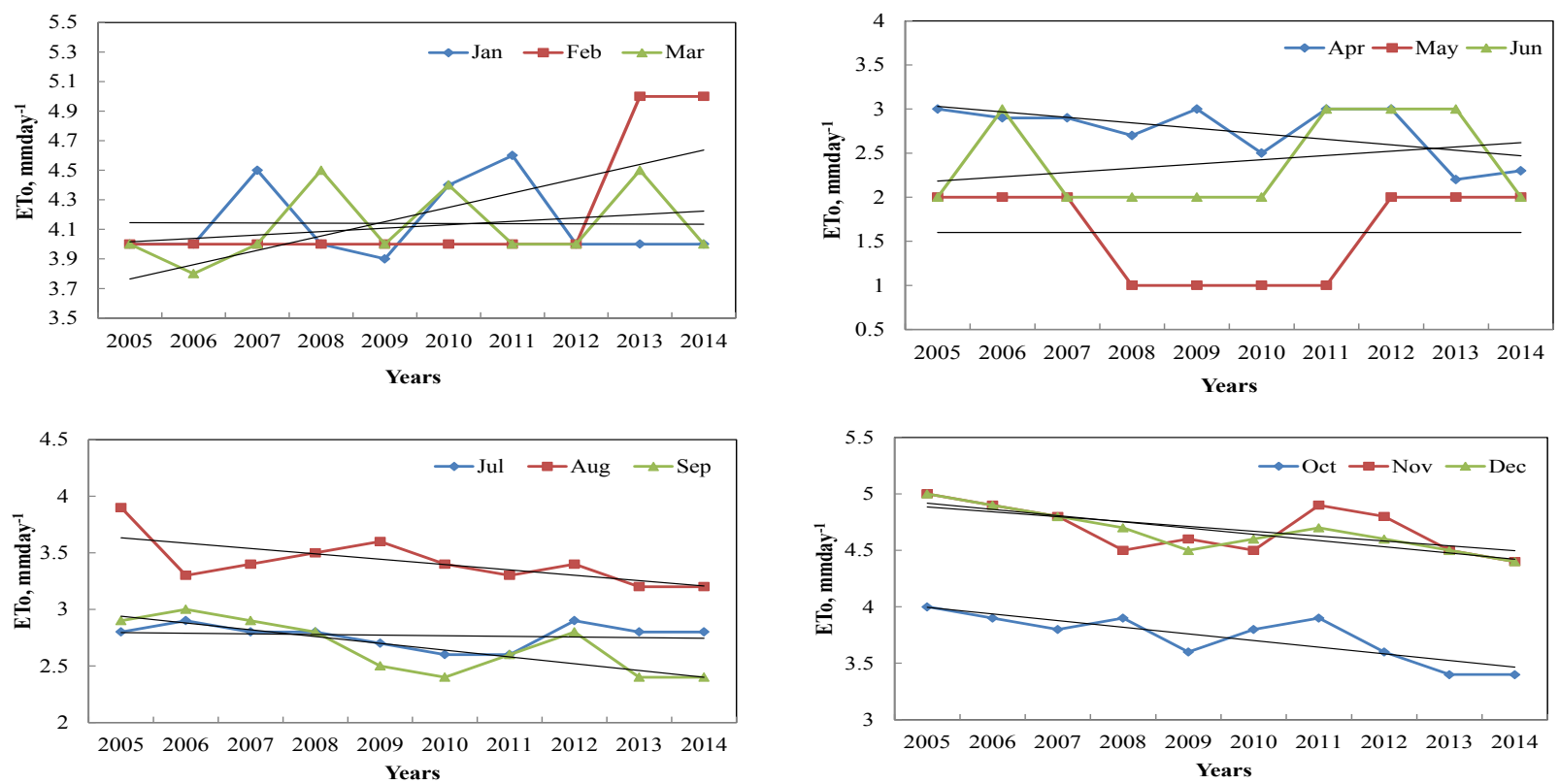

Fig. 2. Three years moving average trends in mean monthly reference evapotranspiration.

(2015). As for most of the months of the year, the monthly reference evapotranspiration showed the decreasing linear trend, the crop water requirement at Akola station may decrease in future.

\section{Conclusion}

From above discussion following findings were drawn

- There was unsteady variation in monthly maximum temperature. The coefficient of variation ranged between $1.85-5.62$ which indicated the variation in maximum air temperature over the year.

- For January to May and December, monthly maximum air temperature showed slightly decreasing trend while for June to November, it showed increasing trend. Thus, in general, the monthly maximum air temperature decreases during summer season while increases over monsoon and winter season.

- For April, August, September, October, November and December the monthly reference evapotranspiration showed decreasing linear trend, while for February, March and June it showed increasing trend, and for January, May and July, it showed somewhat constant linear trend. In general, the monthly reference evapotranspiration showed the decreasing linear trend over monsoon and winter season, whereas increasing trend over summer season.

- Therefore it is concluded that as the monthly reference evapotranspiration is decreasing over cropping seasons i.e. monsoon and winter, at Akola station, the crop water requirement shall decreases in future.

\section{REFERENCES}

Abaurrea J. and Cerian A. C. (2001). Trend and variability analysis of rainfall series and their extreme events. $<$ http:// metodosestadisticos.unizar.es/personales/ acebrian/ publicaciones AbCeSPRIN.pdf.>

Allen R.G., Pereira L.S., Raes D., and Smith M. (1998). Crop evapotranspiration -Guidelines for computing crop water requirements FAO Irrigation and drainage paper 56, <http://www.fao.org/docrep/x0490e/ x0490e00.htm>: 24

Deshmukh M.M., Wadatkar S.B., Meshram R.V. and Kawle M.V. (2015). Ten years moving averages of climatic parameters and its trend analysis. Int. J. Research in Engineering, Science and Technologies, 1(8): 36-47.

Fulekar M. H. and Kale R. K. (2010). Impact of climate change. Indian Scenario, University News, 48(24): 1523

Jhajharia D and Singh V. P. (2011). Trends in temperature, diurnal temperature range and sunshine duration in Northeast India. Int. J. Climatol. 31: 1353-1367

Jhajharia D., Chattopadhyay S., Choudhary R.R., Dev V., Singh V.P. and Lal S. (2013). Influence of climate on incidences of malaria in the Thar Desert, northwest India. Int. J. Climatology, 33: 312-325.

Jhajharia D., Singh V.P., Kumar R and Choudhary R.R. (2014). Searching evidence for the existence of evaporation paradox in arid environments of northwest India. Global NEST Journal, 16: 1-9

Rajendra K. P. (2004). Foreword In: Proc. $22^{\text {nd }}$ Session of the Intergovernmental Panel on Climate Change (New Delhi, 9-11 November, 2004), IPCC., New Delhi, India: 7-8

Xiaomong L., Yuzhou L., Dan Z. M. Z. and Changming L. (2011). Recent changes in pan-evaporation dynamics in Chiana. Geophysical Research letter, 38(13) : 1- 4 